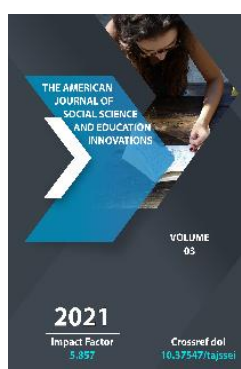

Copyright: Original content from this work may be used under the terms of the creative commons attributes 4.0 licence.

\section{Physical Education In The Structure Of Professional Education}

\author{
Ikromov Isomiddin Ilxomjonovich \\ Teacher Of Sports Games Of Fergana State University, Uzbekistan \\ Yusupov Toir Tolanovich \\ Teacher Of Sports Games Of Fergana State University, Uzbekistan \\ Haitbayeva Barnohon Baxodirovna \\ Master Degree From Fergana State University, Uzbekistan
}

\title{
ABSTRACT
}

Physical culture acts as an integral quality of a personality, as a condition and prerequisite for effective educational and professional activity, as a generalized indicator of the professional culture of a future specialist and as a goal of self-development and self-improvement. It characterizes the free, conscious self-determination of a person who, at different stages of life development, selects and assimilates those values that are most significant for him from a variety of values.

\section{KEYWORDS}

Sport, education, person, health, professional, development, individual, culture.

\section{INTRODUCTION}

Physical culture is an organic part of human culture, its special independent area. At the same time, it is a specific process and result of human activity, a means and method of physical improvement of a person. Physical culture affects the vital aspects of the individual, received in the form of inclinations, which are transmitted genetically and develop in the process of life under the influence of upbringing, activities and the environment. Physical culture satisfies social needs in communication, play, entertainment, in some 
forms of personal self-expression through socially active useful activities. And also, the basis of the socio-cultural being of the individual, the fundamental modification of his general and professional culture.

At its core, physical culture has a purposeful motor activity in the form of physical exercises, which allow to effectively forming the necessary skills and abilities, physical abilities, to optimize the state of health and working capacity.

The student's physical culture, the motivational-value component reflects an actively positive emotional attitude to physical culture, the formed need for it, the system of knowledge, interests, motives and beliefs that organize and direct the volitional efforts of the individual, cognitive and practical activities to master the values of physical culture, focus on healthy lifestyle, physical improvement [2].

As far as sport is a phenomenon of cultural life, sport is a part of physical culture. In it, a person seeks to expand the boundaries of his capabilities, this is a huge world of emotions generated by successes and failures, the most popular spectacle, an effective means of education and self-education of a person, there is a complex process of inter-human relations in it. Sport is a competitive activity and special preparation for it. He lives by certain rules and norms of behaviour. It clearly shows the desire for victory, the achievement of high results, requiring the mobilization of the physical, mental and moral qualities of a person. Therefore, they often talk about the sports nature of people who successfully manifest themselves in competitions [3-5].

Components of physical culture: Physical education, physical development.
- Physical education. Included in the system of education and upbringing, starting from preschool institutions, it characterizes the basis of people's physical fitness - the acquisition of a fund of vital motor skills and abilities, the diversified development of physical abilities. Its important elements are the "school" of movements, the system of gymnastic exercises and the rules for their implementation, with the help of which the child develops the ability to control movements differentiated, the ability to coordinate them in different combinations; a system of exercises for the rational use of forces when moving in space (the main ways of walking, running, swimming, skating, skiing, etc.), when overcoming obstacles, in throwing, in lifting and carrying weights; Ball "school" (playing volleyball, basketball, handball, football, tennis, etc.).

- Physical development is a biological process of formation, changes in the natural morphological and functional properties of an organism during a person's life (length, body weight, chest circumference, the vital capacity of the lungs, maximum oxygen consumption, strength, speed, endurance, flexibility, agility, etc.)[2,6].

The professional orientation of a person's physical culture is the basis that unites all its other components. Objective and subjective indicators are the criteria by which one can judge the forced physical culture of a person. Based on them, it is possible to reveal the essential properties and measure of manifestation of physical culture inactivity. These include: 
- The degree of formation of the need for physical culture and the ways of its satisfaction;

- The intensity of participation in physical culture and sports activity (time spent, regularity);

- The nature of the complexity and the creative level of this activity;

- The severity of emotional-volitional and moral manifestations of a personality in physical culture and sports activity (independence, perseverance, purposefulness, self-control, collectivism, patriotism, hard work, responsibility, discipline);

- The degree of satisfaction and attitude to the performed activity;

- Manifestation of amateur performance, self-organization, self-education, selfeducation and self-improvement in physical culture;

- The level of physical perfection and attitude towards it;

- Possession of the means, methods, abilities and skills necessary for physical improvement;

- Consistency, depth and flexibility of assimilation of scientific and practical knowledge on physical culture for creative use in the practice of physical culture and sports activity;

- The breadth of the range and the regularity of the use of knowledge, abilities, skills and experience of physical culture and sports activities in the organization of a healthy lifestyle, in educational and professional activities. [3]

Thus, the formation of a person's physical culture can be judged by how and in what specific form personal attitudes towards physical culture and its values are manifested.
A complex system of individual needs, her abilities appears here as a measure of mastering the physical culture of society and a measure of creative self-expression in it.

In connection with the results of the article, thanks to professionally applied physical culture, prerequisites are created for the successful mastering of a particular profession and the effective performance of work. In production, this is introductory gymnastics, physical education pauses, physical education minutes, after working rehabilitation exercises, etc.

The content and composition of the means of professionally applied physical culture, the procedure for their use are determined by the peculiarities of the labour process. In the conditions of military service, it acquires the features of a military professional physical culture.

\section{REFERENCES}

1. F50 Physical culture of a student: Textbook / Ed. IN AND. Ilyinich. M .: Gardariki, 2000 .-- 448 p.

2. Baldaev K.V. Outdoor games at the stage of initial sports specialization in freestyle wrestling. Abstract of the thesis. Diss .... kan.ped.nauk.-M., 1986. - 22p.

3. Andris E.R., udratov R.Q. Engil athletics / T. - 1998 - 124 p.

4. Nagovitsyn, R. S., Senator, S. Y., Maximova, E. B., Neverova, N. V., \& Sokolnikova, E. I. (2017). Continuous professional education of teachers of physical education with the additional qualification in the field of foreign languages on the basis of competencybased approach. Journal 
of Physical Education and Sport, 17(3), 2170-2178.

5. Khalilovna, O. N., Axmatjanovna, M. M., Kosimovich, N. U., \& Botirovna, K. V. (2020). Main core and meaning of shaping professional faith. Journal of Critical Reviews, 7(2), 242-245.

6. Khalilovna, O. N., Lutfullayevna, B. L., Kosimovich, N. U., \& Yusupovna, R. M. (2020). Historical studies in the pedagogical training and ways to improve vocational training. Journal of Critical Reviews, 7(3), 274-277. 